\title{
The allegorical sense of Gregory the Great's commentary on the Song of Songs
}

In the history of biblical hermeneutics, the text of the Song of Songs $(\mathrm{Sg})$ has been primarily interpreted according to its spiritual-allegorical and literary-historical senses. The allegorical interpretation prevailed in Antiquity and in the Middle Ages (Hippolytus, Origen Adamantius, Gregory of Nyssa, Aurelius Ambrosius, Augustine of Hippo) whereas the literary-historical interpretation is typical of contemporary biblical hermeneutics (Roland E. Murphy, Osvald Loretz, Günter Krinetzki, Lloyd G. Carr, Gianfranco Ravasi). Followers of the spiritual-allegorical interpretation presented the meaning of Sg as an allegory through which the inspired author, using the love of man to woman as a metaphor, extolled the love of God for man, soul, believer, Israel, and the Church. With that in view, the religious interpretation of the text was of the utmost significance. However, contemporary exegesis treats the text literally, as love poem in which the inspired author praises the marital love of man for woman as a desired love given to man by God. In the following article, I am going to discuss the allegorical sense of the commentary on $\mathrm{Sg}$ written by Gregory the Great (540-604). First, I intend to bring up the issue of the message of the commentary, then the relation between Gregory I's text and earlier commentaries on $\mathrm{Sg}$, in order to finally discuss the allegorical aspect of Gregory I's Commentary on the Song of Songs.

\section{The message}

According to the most recent codicological studies of Commentary on the Song of Songs by Pope Gregory the Great, this text has survived in 176 manuscripts. Unfortunately, we are not in the possession of the full commentary on Sg by Gregory I as the manuscript breaks off on $\mathrm{Sg} 1: 8 .^{1}$ The number of manuscripts confirming

\footnotetext{
${ }^{1}$ R. Bélanger, Introduction, [in:] Grégoire le Grand, Commentaire sur le Cantque des Cantiques, Sources Chrétiennes (hereinafter referred to as: SCh) 314, Paris 1984, p. 15-22; C. Leonardi, Introduzione, [in:] Gregorius Magnus, Expositio in Canticis Canticorum, text: R. Bélanger, ed. C. Leonardi, Gregorii
} 
that Gregory the Great was the author of the aforementioned commentary may rise to 230 or so. It is assumed that in all probability, $30-40 \%$ of the extant manuscripts have not been codified yet, since the libraries that own those earlier mentioned Expositio in Canticis Canticorum manuscripts have not catalogued them. ${ }^{2}$

Gregory did not write this commentary at a table. Like his other works, the commentary on $\mathrm{Sg}$ was initially presented as an oral teaching, which was scrupulously recorded by so-called notarii, shorthand typists of that time trained in tachygraphy. That is why the text was originally written on index cards, which the Pope passed on to his friend Claudius to transform them into a continuous text. Gregory I also entrusted Claudius with a record of his teachings regarding the commentary on the Book of Proverbs, some prophets, the Book of Kings and Heptateuch. ${ }^{3}$

Claudius was a monk and an abbot at the monastery of St. John and Stephen in Classe, in the outskirts of Ravenna. The monastery enjoyed many privileges already granted by Pope Gregory the Great, ${ }^{4}$ though it was destroyed in the $9^{\text {th }}$ century. ${ }^{5}$ Gregory I stated in the year 602 that Claudius had heard the papal interpretation of the text and that the aforementioned monk spent four years in Rome. ${ }^{6}$ We can deduce from the above that Gregory's Commentary on the Song of Songs was created between 594 or 595 and 598. When Claudius died, Pope Gregory asked subdeacon John of Ravenna to send him in Rome the material Claudius had been working on. Unfortunately, it turned out that Claudius, who was meant to convey the meaning of the Pope's words and fill in the shorthand cards created on the basis of Gregory I's oral statements, did not do the task he was entrusted with well. In 599, when Gregory was reading the addenda made by Claudius, he noticed that the discrepancy

Magni Opera (hereinafter referred to as: GMO) 8, Roma 2011, s. VII; por. Bibliotheca Gregorii Magni, Archivum Gregorianum 10, Firenze (in preparation).

${ }^{2}$ P. Verbraken, La tradition manuscrite du Commentaire de Saint Grégoire sur le Cantique des cantiques, "Revue Bénédictine" 73 : 1963, p. 277-288; idem, Un nouveau manuscrit du commentaire de saint Grégoire sur le Cantiques des cantiques, "Revue Bénédictine" 75 : 1965, p. 143-145; T. De Robertis, Un nuovo testimone delle «Homiliae in Hizechihelem.» Il palinsesto Riccardiano 1221/2 (Ilias Latina), Archivum Gregorianum 2, Firenze 2005; D. Frioli, Gregorio Magno e l'invenzione del Medioevo - Schede: 2", 7", 11", 19”, 20”, 21", 27”, 28”, 31", 34”, 38”, [in:] Gregorio Magno e l'invenzione del Medioevo, ed. L. G. C. Ricci, Archivum Gregorianum 9, Firenze 2006, p. 75-79; 87-89, 97-99, 115-117, 117-118, 119-121, 131-135, 135-137, 141-142, 147-149, 157-158; D. Frioli, L. Castaldi, Gregorio Magno e l'invenzione del Medioevo - Scheda 10", [in:] Gregorio Magno e l'invenzione del Medioevo, p. 95-97; D. Frioli, F. Crivello, Gregorio Magno e l'invenzione del Medioevo - Schede 16", 17”, [in:] Gregorio Magno e l'invenzione del Medioevo, p. 109-109, 111-113.

${ }^{3}$ L. Castaldi, "L'Archivium Lateranense” e la trasmissione delle opera di Gregorio Magno, [in:] Gregorio Magno e l'invenzione del Medioevo, p. 67-71.

${ }^{4}$ Gregorius Magnus, Epistulae 7, 40, GMO 5/2, 502.504; ibidem 8, 17, GMO 5/3, 56.58.

${ }^{5}$ G. Picasso, «Quam sit necessarium monasteriorum quieti prospicere» (Reg. Epist 8.17). Sulla fortuna di un canone gregoriano, [in:] Cristianità ed Europa. Miscellanea di studi inonore di Luigi Prosdocimi, ed. C. Alzati, vol. 2, Roma-Freiburg-Wien 2000, p. 95-105; P. F. Kehr, Italia Pontificia, vol. 5, Berolini $1911\left(1961^{2}\right)$, p. 108-109.

${ }^{6}$ Gregorius Magnus, Epistula 12, 6, GMO 5/4, 180-184. 
between the meaning of his commentary and the text penned by the monk Claudius was too great. The Pope therefore asked subdeacon John to go to the monastery of St. John and Stephen in Classe, rectify the aforementioned mistakes and send the corrected version of the commentary to the Pope. ${ }^{7}$

Claudio Leonardi assumed that the papal commentary on $\mathrm{Sg}$ was put into circulation without Gregory having revised the full text, as the Pope would only have corrected the excerpt $1: 1-8$. However, regardless of this hypothetical-final revision, the text of the commentary as we have it at present shows some signs of a revision made by Gregory I himself and has features characteristic of the original oral version of the text (e.g., the prologue demonstrates linguistic and doctrinal cohesion, which simply leads to the assumption that a revision of the text was made but also retains some features of the spoken text, such as the "omnis auditor" appeal). There is no denying that the commentary under discussion is a work typical of Gregory the Great. ${ }^{8}$

\section{The relation between Gregory's commentary on the Song of Songs and the Sg commentaries of Origen, Augustine and Aponius}

The commentary on Sg by Gregory I has some similarities to the earlier commentaries written by Origen, Augustine and Aponius. The Pope refers mostly to the Bible itself: there are 150 biblical quotes and references in 46 articles of Gregory's commentary, 70 from OT (10 from the prophets, 16 from Ps, 5 from Pr, 2 from Qo, 3 from $\mathrm{Si}, 10$ from $\mathrm{Gn}, 5$ from Ex, $1 \mathrm{Nb}, 2$ from $\mathrm{Dt}, 1$ from $\mathrm{Jg}, 3$ from $1 \mathrm{~K}, 1$ from Tb, 2 from $2 \mathrm{M}, 1$ from $\mathrm{Jb}$ ) and 80 from NT (40 from the letters of Paul, 5 from Heb, 35 from the Gospels, Acts of the Apostles, Epistles of John and from Revelations). Gregory used the Vulgate ${ }^{9}$ translation of the Bible, which explains where the differences between the Latin translation of St. Jerome and the original Hebrew text come from.

The comparative study of Origen's and Gregory's commentaries shows that Pope Gregory I was familiar with Origen's homilies and commentary on Sg and used his writings while working on his own text, but only sparingly. The text of Gregory I's commentary on $\mathrm{Sg}$ reaches verse $1: 8$, whereas Origen took the text of his Homilies on the Song of Songs to verse $2: 14^{10}$ and in the text of his Commentary on the Song

${ }^{7}$ P. Mayvaert, The Date of Gregory the Great's Commentaries on the Canticle of Canticles and on I Kings, "Sacri erudiri” 23 : 1978-1979, p. 192-220; A. De Vogüé, Les vues de Grégoire le Grand sur la vie religieuse dans son commentaire des Rois, "Studia Monastica" 20 : 1978, p. 17-63; R. Bélanger, Introduction..., SCh 314, p. 22-28.

${ }^{8} \mathrm{C}$. Leonardi, Introduzione..., IX.

${ }^{9}$ R. Bélanger, Introduction, [in:] Grégoire le Grand, Commentaire sur le Cantique des Cantiques, SCh 314, Paris 1984, p. 63.

${ }^{10}$ Origène, Homélies sur le Cantique des Cantiques, $\mathrm{SCh} 37$ bis, Introduction, traduction et notes par Dom Olivier Rousseau, Paris $2007^{2}$. 
of Songs he reached verse $2: 15 .{ }^{11}$ In Origen's oral commentary on $\mathrm{Sg}$, it seems that some of the thoughts and phrases used by the Alexandrian were so suggestive for the Pope that they remained in his deliberations on the text. Gregory I undoubtedly took from Origen the general approach, some phrases, and at times the way in which exegesis of a certain extract was executed. ${ }^{12}$

Origen arranged his commentary on Sg by headwords, a similar structure to the one he applied in his Homilies on the Song of Songs. It can be noticed in his commentary on $\mathrm{Sg}$ that Origen took into consideration the development of the dramatic plot and especially the relationship between the four people. Then he proceeded to explain, with precision and in sequence, the biblical text according to its literal and spiritual sense. ${ }^{13}$ When it comes to the spiritual understanding, the Alexandrian distinguished between the interpretation focused on the Christ-Church relation and the one focused on the Christ-soul relation. What is more, he also accentuated that the relationship between the bride and the bridegroom depicted in $\mathrm{Sg}$ constitutes the type of relation between Christ and the Church, or is a figure of mystical relation between God and man or Christ and the soul. ${ }^{14}$ Origen used a typological approach to explain the Bible, often making numerous references to biblical quotes and allegories. Nonetheless, the combination of biblical text and a pagan content is scarcely seen. ${ }^{15}$

The mystical interpretation of the $\mathrm{Sg}$ text was also important for Origen. ${ }^{16}$ From this vantage point, the relationship between the bride and the bridesmaids (maidens) in $\mathrm{Sg}$ was for the Alexandrian a starting point for describing the condition of an imperfect soul (as symbolised by the bridesmaids) who wanted to meet the bridegroom (the symbol of Christ/ God) but never did. On the other hand, the bride (the symbol of a perfect soul/ the Church) enjoys the union with the groom (Christ/God), which for Origen-would describe in a mystical sense the contemplative and unifying love of God. ${ }^{17}$ According to spiritual-mystical interpretation, the protagonists of $\mathrm{Sg}$ are the Church and the soul

${ }^{11}$ Origène, Commentaire sur le Cantique des Cantiques, vol. 1 (livres I-II), vol. 2 (livres III-IV), SCh p. 375-376, texte de la version latine de Rufin, Introduction, traduction et notes par L. Brésard, H. Crouzel, M. Borret, Paris 1991-1992.

${ }^{12}$ C. Leonardi, Introduzione..., XIV.

${ }^{13}$ M. Simonetti, Cantico dei Cantici (scritti esegetici su), [in:] Origene. Dizionario. La cultura, il pensiero, le opere, ed. A. Monaci Castagno, Roma 2000, p. 60-64.

${ }^{14} \mathrm{~J}$. Chénevert, L'Église dans le Commentaire d'Origène sur le Cantique des Cantiques, BruxellesParis-Montreal 1969; F. Ledegang, Mysterium ecclesiae: images of the church and its members in Origen, Leuven 2001.

${ }^{15}$ A. Ceresa-Gastaldo, L'esegesi origeniana al Cantico dei Cantici, [in:] Origeniana Secunda, Roma 1980, p. 245-252; A. M. Pelletier, Lectures du Cantique des cantiques. De l'énigme du sens aux figures du lecteur, Analecta Biblica 121, Roma 1989.

${ }^{16}$ T. Heither, Origenes "Mystikverständnis " in seinem Hohelidkommentar, "Erbe und Auftrag" 74 : 1998 , p. $478-494$.

${ }^{17}$ A. Ceresa-Gastaldo, La dimensione dell'amore nell'interpretazione origeniana del Cantico dei Cantici, [in:] Paradoxos Politeia. Studi patristici in onore di Giuseppe Lazzati, Milano 1979, p. 187-194; H. Pietras, L'amore in Origene, Studia Ephemeridis Augustianum 28, Roma 1988. 
which, attracted by Christ after a period of asceticism in which they become closer to God, enter the path of contemplation, which is the process of unification with God. The Church and the soul are depicted by Origen as a desiring bride, ready to meet with the bridegroom which is Christ/God. The maidens, who are the symbol of the people who follow the bridegroom but do not meet him, constitute the bride's antithesis, and the reason why their meeting never takes place is the maidens' imperfection. Just as the girls do not meet and unite with the bridegroom, the imperfect souls do not desire Christ or prepare for meeting Him through asceticism, and as a result, they are not chosen by Him and do not unite with Him. In Origen's Homilies on the Song of Songs, which are much shorter than his Commentary, he focuses mostly on the topic of mystical perfection (Christ's kiss on the lips, the touching of the bride by the bridegroom, the unification with the groom, the joy of the bride from the milk given by the bridegroom, the sense of being chosen by the bride) and the imperfection of an ordinary believer (Moses, the Prophets, OT).$^{18}$

Gregory the Great copies Origen's triple (literal, moral, allegorical) and quadruple methods of interpreting the Bible (literal, moral, anagogic, spiritual), and he clearly copies these exegetical readings of $\mathrm{Sg}$ in accordance with the principles of mystical interpretation. Sg is not a love song of two lovers for Gregory I but, both in the intention of an inspired author and in the words of the Bible, a symbolic text in which the relationship between a man and a woman symbolizes the marriage of Christ with the soul. ${ }^{19}$ The presence of Origen's interpretation in Gregory I's commentary on $\mathrm{Sg}$ can be clearly seen in the prologue and in the commentary itself. Just like Origen, Gregory explains the reduplication in the title of the book ${ }^{20}$ and the different types of songs present in the Holy Bible ${ }^{21}$; refers to the triple sense of the Bible 22 ; evokes the four dramatic personae of $\mathrm{Sg}$ (the bridegroom, the bride,

${ }^{18}$ A. Ceresa-Gastaldo, Variazoni ermeneutiche nella tradizione rufiniana del "Commento al Cantico dei Cantici" di Origene, Antichità Altoadriatiche XXXIX, Udine 1992, p. 125-130; A. M. Pelletier, Le Cantique des cantiques. Un texte et ses lectures, [in:] Les nouvelles voies de l'exégèse. En lisant le Cantique des cantiques. XIXe congrès de l'Association catholique pour l'étude de la Bible (Toulouse, septembre 2001), études réunies sous la dir. de J. Nieuviarts et P. Debergé, Lectio divina 190, Paris 2002, p. 75-101.

${ }^{19}$ P. Meyvaert, A New Edition of Gregory the Great's Commentaries on the Canticle and I Kings, "Journal of Theological Studies" 19 : 1968, p. 215-225; R. Bélanger, Introduction..., SCh 314, p. 43-49; J. M. Petersen, The Influence of Origen upon Gregory the Great's Exegesis of the Song of Songs, "Studia Patristica" 18/1 : 1985, p. 343-347.

${ }^{20}$ Origenes, Homiliae in Canticum canticorum 1, 1, GCS 33, p. 27; cf. Gregorius Magnus, Expositio in Canticis Canticorum 6, GMO 8, 6.

${ }^{21}$ Origenes, Commentarium in Canticum canticorum Prol. 5, GCS 33, p. 80-83; cf. Gregorius Magnus, Expositio in Canticis Canticorum 7, GMO 8, 8.

${ }^{22}$ Origenes, Commentarium in Canticum canticorum Prol. 4, GCS 33, p. 76-79; cf. Gregorius Magnus, Expositio in Canticis Canticorum 9, GMO 8, 10. 
the maidens, the friends of the bridegroom $)^{23}$; interprets the bride's long wait for the bridegroom as humankind and the Church awaiting the Intermediary of God and men $^{24}$; interprets the bride's intuition of the bridegroom's presence as a recognition of the Incarnation of the Son of God by the $\mathrm{Church}^{25}$ and wine as the instructions of the law and OT prophets. ${ }^{26}$

On the other hand, the correspondence between Commentary on the Song of Songs by Gregory I and the commentaries written earlier by Augustine of Hippo and Aponius exists basically at the doctrinal level, but not the literal one. ${ }^{27}$ There is only one literal similarity between Augustine's and Gregory's commentaries on Sg, in which Gregory, commenting on $\mathrm{Sg} 1: 6$, uses the same terminology as Augustine: "requiescere"28 and "in feruore caritatis". ${ }^{29}$ Finally, in regards to Aponius's commentary, two literal similarities to the text of Gregory I can be noticed. ${ }^{30}$

\section{The allegorical sense of Gregory I's commentary on the Songs of Songs}

In his commentary on $\mathrm{Sg}$, Gregory I followed the principles of intellectual and paranetic interpretation, which is why his commentary does not exhibit features of an exegetical treatise or the structure of a homily. It was rather a simple pastoral exegesis which tapped into the works of earlier exegetes and had a paranetic

${ }^{23}$ Origenes, Commentarium in Canticum canticorum Prol. 1, GCS 33, p. 61; cf. Gregorius Magnus, Expositio in Canticis Canticorum 10, GMO 8, 12.

${ }^{24}$ Origenes, Commentarium in Canticum canticorum I, GCS 33, p. 90; cf. Gregorius Magnus, Expositio in Canticis Canticorum 12, GMO 8, 12.

${ }^{25}$ Origenes, Commentarium in Canticum canticorum I, GCS 33, p. 92; cf. Gregorius Magnus, Expositio in Canticis Canticorum 13, GMO 8, 12.14.

${ }^{26}$ Origenes, Commentarium in Canticum canticorum I, GCS 33, p. 94; cf. Gregorius Magnus, Expositio in Canticis Canticorum 13, GMO 8, 14.

${ }^{27}$ R. Bélanger, Introduction, SCh 314, p. 30-41; A. M. La Bonnardière, Le Cantique des cantiques dans l'oeuvre de saint Augustin, "Revue des études augustiniennes" 1 : 1955, p. 225-237; F. B. A. Asiedu, The Song of Songs and the Ascent of the Soul: Ambrose, Augustine and the Language of Mysticism, "Viligiae Christianiae" 55 : 2001, p. 299-317.

${ }^{28}$ Aurelius Augustinus Hipponensis, Sermones 138, 7: "in quibus maxime requiescis" (NBA 31/1, 312); cf. Gregorius Magnus, Expositio in Canticis Canticorum 42: "indica in quorum corda ueraciter requiescis" (GMO 8, 36).

${ }^{29}$ Aurelius Augustinus Hipponensis, Sermones 295, 5.5: "in splendore veritatis, in fervore caritatis," NBA 33, 316; cf. Gregorius Magnus, Expositio in Canticis Canticorum 42: "id est ubi requiescas in feruore caritatis" (GMO 8, 36).

${ }^{30}$ (1). Aponius, Expositio in Canticum Canticorum: "Christi et ecclesiae copulam cecinerunt" (PLS I, 806); cf. Gregorius Magnus, Expositio in Canticis Canticorum 8: "coniunctio uerbi et carnis, Christi et ecclesiae, celebrata est" (GMO 8, 10); (2). Aponius, Expositio in Canticum Canticorum: "recondito in corporeo uasculo [...] nunc quasi effuso uase unguenti in dom, cunctis innotescit," PLS I, 810; Gregorius Magnus, Expositio in Canticis Canticorum 21: "si enim sit unguentum in uasculo [...] si enim non se effunderet, nequaquam nobis innotesceret” (GMO 8, 20). 
application. Gregory I's primary interest was to extract from the text of Sg its spiritual and mystical meaning. ${ }^{31}$ Commenting on the text, Gregory I followed Origen by passing over the literal interpretation and trying to find in Sg a typological and mystical pattern. ${ }^{32}$ Unlike Origen's commentary, however, Gregory I's text pauses a few times on the commented entry, each time providing alternative interpretations of the text or important explanations. ${ }^{33}$

In Gregory I's opinion, humankind, after the banishment from Eden, is in its current life spiritually blinded, ${ }^{34}$ as it is outside of God and exists in a state of cold insensibility. ${ }^{35}$ That is why man does not understand the voice of God of his own accord, the voice that calls the people, "Follow God" or "Love God". ${ }^{36}$ The word of God acting upon the inner life of a man ("the cold and insensible soul," Exp. C.C. 1) addresses him through mystifying allegories and, in this way, "mysteriously introduces the soul from the matters that he knows of, to the love that it does not know". ${ }^{37}$ Allegory, in Gregory I's opinion, becomes a kind of machine ("machina") that allows the soul to rise to God. It is because of this allegory that the soul understands the words of the Scripture not recognized before. Through understanding the allegory in the biblical text, the soul attains the internal intelligence that lets it spiritually recognize the words of God conveyed through external human terminology ${ }^{38}$ During the allegorical reading of the word of God, God Himself acts upon man to open him from within (literally to open our heart, "cor nostrum") to the love of God. ${ }^{39}$

Gregory compares the very text of the Bible to the mountain that Christ the Lord descends to enter human hearts and to let the people meet Him in person. The mountain/Holy Bible is filled with the thoughts of God which are, however, hidden behind allegories. Only a man who does not try to reduce the meaning of the biblical text to purely human, subjective interpretations can ascend the mountain, that is, understand the meaning of the Scripture. Also a man who does wrong, who does

${ }^{31}$ P. Verbraken, Introduction, [in:] Gregorii Magni, Expositiones in Canticum Canticorum, In librum Primum Regum, CChSL 144, Turnholti 1963, VIII; V. Recchia, L'esegesi di Gregorio Magno al Cantico dei Cantici, Torino 1967, p. 1-26; G. Cremascoli, L'esegesi biblica di Gregorio Magno, Brescia 2001, p. 35-51.

${ }^{32}$ Gregorius Magnus, Expositio in Canticis Canticorum 4, GMO 8, 2.4.

${ }^{33}$ E. A. Matter, The Voice of My Beloved. The Song of Songs in Western Medieval Christianity, Middle Ages series, Philadelphia 1990, p. 94-95; C. Leonardi, Introduzione..., XVI.

${ }^{34}$ Gregorius Magnus, Expositio in Canticis Canticorum 1: "postquam a paradisi [...] genus humanum, in istam peregrinationem uitae praesentis ueniens caecum cor ab spiritali intellectu habet" (GMO 8, 2).

${ }^{35}$ Gregorius Magnus, Expositio in Canticis Canticorum 1: "foris missum et per torporem insensibilitatis frigidum non caperet quod audiret" (GMO 8, 2).

${ }^{36}$ Gregorius Magnus, Expositio in Canticis Canticorum 1: "caeco cordi si diceretur uoce diuina: «Sequere deum» uel «Dilige deum»" (GMO 8, 2).

${ }^{37}$ Gregorius Magnus, Expositio in Canticis Canticorum 1: "de rebus, quas nouit, latenter insinuat ei amorem, quem non nouit" (GMO 8, 2).

${ }^{38}$ Gregorius Magnus, Expositio in Canticis Canticorum 2, GMO 8, 2.

${ }^{39}$ Gregorius Magnus, Expositio in Canticis Canticorum 3, GMO 8, 2. 
not follow the path of love and disobeys the other Commandments of God, will not be able to comprehend the message of the Bible. The Scripture should be read spiritually, as the first effect of reading the Bible properly is the ignition of the spirit of love in the reader, who is filled not with himself and his own thoughts, but with the Holy Spirit. Having been filled with the Holy Spirit, the soul of the reader goes away from evil and is granted the gift of the contemplation of God. ${ }^{40}$ The text of the Song of Songs reveals a holy and intimate secret of the contact and union of man with God, ${ }^{41}$ which is disclosed only to those who are endowed with secret spiritual intelligence ("secretum in occultis intellegentis penetratur"). ${ }^{42}$ By learning and performing other biblical songs, a believer avoids his vices and the devil is cast away (e.g., Mary's song from Ex $15: 21$; the song of Moses from Dt 32 : 1; Anna's song

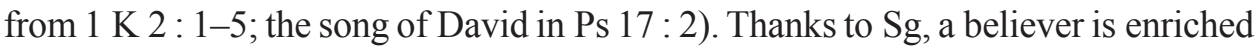
with virtues, and the Lord unites with the congregations through an intimate, familial love ("dominus familiari amore conplecitur")..$^{43}$

Gregory pointed out that God in the Bible is referred to by many names by believers: the Lord ("since he created us"), the Father ("as he adopted us"), the Husband ("because he was united with us"). In $\mathrm{Sg}, \mathrm{He}$ is also addressed by this last name, as He united with the Church in an expression of fear and internal love. ${ }^{44}$ Every soul, if it has the fear of God, has already entered a relationship with God. With every step in the direction of God, the fear of the soul desiring God is replaced with the grace of love. Whenever the soul distributes alms to those in need or devotes life to good deeds (which are compared to an invitation to a reception table; kissing the footsteps of the Lord by a woman described in $\mathrm{Lk} 7: 45-46),{ }^{45}$ those acts represent meeting with God (through the symbolism of being kissed by the bridegroom/Lord).

The Pope, emphasising the spiritual significance of reading the books of the Bible gradually, pointed out this concurrent spiritual development of the reader. First, it is necessary to correct your ways of conduct (personal habits, acting justly). Then, the physical world around us needs to undergo ascetic reflection and one needs to learn how to alienate oneself from this world ("accept as non-existent all the things that exist," "do not value the decent things in this world as well"). The last stage of becoming closer to God is the contemplation of Godly matters, achieved by the spiritual sense of a pure heart. With the voice of the Church, every soul can

\footnotetext{
${ }^{40}$ Gregorius Magnus, Expositio in Canticis Canticorum 5, GMO 8, 6.

${ }^{41}$ Gregorius Magnus, Expositio in Canticis Canticorum 7: "Canticum uero coniunctionis cum deo hoc est canticum, quod in nuptiis sponsi et sponsae canitur" (GMO 8, 8).

${ }^{42}$ Gregorius Magnus, Expositio in Canticis Canticorum 6, GMO 8, 6.

${ }^{43}$ Gregorius Magnus, Expositio in Canticis Canticorum 7, GMO 8, 8.

${ }^{44}$ Gregorius Magnus, Expositio in Canticis Canticorum 8, GMO 8, 8.10.

${ }^{45}$ Gregorius Magnus, Expositio in Canticis Canticorum 18, GMO 8, 16.18.
} 
recognize and see in its heart the entrance to God ("entrance of the bridegroom to the wedding chamber"). ${ }^{46}$

Sg [1 : 1] (Douay-Rheims Bible: "Let him kiss me with the kiss of his mouth") Spiritual gifts to date sent by God via the angels, patriarchs or prophets were the gifts of the servants of the Lord. However, all humankind, as equated with the Church or the bride, awaits the presence of the bridegroom, which is Jesus Christ and His spiritual gifts, words and presence. ${ }^{47}$ The fact that the bride senses the presence of the bridegroom can be interpreted spiritually as a description of the gift of the Creator for all His creations: "when searching for Him we speak of Him, we can enjoy His presence". ${ }^{48}$

Sg [1 : 1-2] (Douay-Rheims: "for thy breasts are better than wine, smelling sweet of the best ointments") Wine is alternately the knowledge coming from the law and given by the prophets (Exp. C.C. 13), the knowledge of heathen philosophers filled with arrogance (Exp. C.C. 16), the experience of God while still living our earthly life (Exp. C.C. 19), or, the knowledge full of hubris which intoxicates the one who studies it (Exp. C.C. 30). When the Lord arrives, this knowledge is transfigured into milk coming from the bodily breasts. Understood symbolically, the breasts denote the revelation of the divinity of Christ in His humble incarnation. By proclaiming the good tidings of His salvation in real life, Jesus convinced the people about God, therefore, physically managing to do something that Jewish law had not been able to achieve. ${ }^{49}$ Another explanation of the breasts as symbolism is their comparison to the Holy Saints of God, who in their hearts became similar to the Lord (the Apostles, church preachers). ${ }^{50}$

The smell of the Lord is the Holy Spirit and the Lord's Virtues. Practicing virtues by the Church enlightens the Christians, allows them to grow in the knowledge of divinity, whereas the smells of the law were assigned by the angels in the presence of the Lord. However, just as the very presence of the Lord surpasses the gift from

\footnotetext{
${ }^{46}$ Gregorius Magnus, Expositio in Canticis Canticorum 9, GMO 8, 10. More about the doctrine of the spiritual senses in Christian Antiquity and Middle Ages, see: K. Rahner, Le début d'une doctrine des cinq sens spirituals chez Origène, "Revue d'ascetique et de mystique" 13:1932, p. 113-145; K. Rahner, La doctrine des "sens spirituels» au Moyen Age en particulier chez S. Bonaventure, "Revue d'ascetique et de mystique" 14 : 1933, p. 263-299; M. Olphe-Galliard, Les sens spirituels dans l'histoire de la spiritualité, [in:] Nos sens et Dieu, "Études carmélitaines" 2 : 1954, p. 179-193; B. Fraigneau-Julien, Les sens spirituels et la vision de Dieu selon Symeon, le Nouveau Theologien, Theologie historique 67, Paris 1985; F. M. Tedoldi, La dottrina dei cinque sensi spirituali in san Bonaventura, Roma 1999.

${ }^{47}$ Gregorius Magnus, Expositio in Canticis Canticorum 12, GMO 8, 12.

${ }^{48}$ Gregorius Magnus, Expositio in Canticis Canticorum 13, GMO 8, 12.

${ }^{49}$ Gregorius Magnus, Expositio in Canticis Canticorum 13, GMO 8, 14; Gregorius Magnus, Expositio in Canticis Canticorum 16, GMO 8, 16.

${ }^{50}$ Gregorius Magnus, Expositio in Canticis Canticorum 28, GMO 8, 26. On the significance of church preachers ("rectores") in the thought of Gregory I's, see: R. A. Markus, Gregory the Great and His World, Cambridge 1997, p. 17-33.
} 
the Lord, in the same way, His virtues surpass Jewish law ${ }^{51}$ or pagan virtues. ${ }^{52}$ For this reason, Christ's Virtues are practiced by the Church (especially the virtues of knowledge, purity, mercy, humility and love, contemplation of God).$^{53}$ The soul that desires gifts from God (Exp. C.C. 21), having learned about them through prophecy, becomes enlightened with the grace of God and starts to understand the gifts of God of its own accord. The kiss of the bridegroom is interpreted by Gregory as the moment in which the soul becomes acquainted with the gifts of God through its spiritual intelligence and experiences internal grace, which then comes not from the prophecies of the preachers, but from the internal contact of the soul with God. ${ }^{54}$

Sg [1:2] (Douay-Rheims: "therefore young maidens have loved thee") The maidens symbolise the souls that were chosen and renewed in the sacrament of baptism, which desire the bridegroom/Lord. However, the young age of the maidens indicates that they have not devoted themselves eagerly to the love of the groom/Lord yet..$^{55}$ Their age can also be interpreted as a spiritual weakness, which you grow out of to enter the state of invincible spirituality of the angels. ${ }^{56}$

Sg [1 : 3] (Douay-Rheims: "Draw me") According to Gregory's symbolic interpretation, this is the voice of human nature itself, which is incapable of emulating God of its own accord, and therefore cries to God to let it follow in His footsteps. ${ }^{57}$ Sg [1 : 3] (Douay-Rheims: "we will run after thee to the odour of thy ointments") The smell of the bridegroom's perfumes is the breath of his spiritual gifts which believers want to experience. Gregory introduces the distinction between the believers who walk after the Lord (the lukewarm in faith), those who run (the zealous in faith) and those who run very fast (the zealous and persistent in faith). The ones who run after God, are those believers who treat seriously the commandments of God, who prefer God's will over their own, and perform some deeds that bring them spiritually closer to God. The speed of running after God can be increased by both loving and fearing God (by not trespassing against His commandments). ${ }^{58}$

Sg [1 : 4] (Douay-Rheims: "The king hath brought me into his storerooms: we will be glad and rejoice in thee") According to the spiritual interpretation, the chamber of the king (the storeroom) represents the Holy Church. All those of faith have already crossed the gate to the chamber, and this gate leads into other royal chambers. Those who have faith can likewise attain all other spiritual virtues. The virtue of hope is the equivalent of a threshold and the steps leading to a house ("hope elevates the heart to desire heavenly matters and to leave earthly

\footnotetext{
${ }^{51}$ Gregorius Magnus, Expositio in Canticis Canticorum 14, GMO 8, 14.

${ }^{52}$ Gregorius Magnus, Expositio in Canticis Canticorum 17, GMO 8, 16.

${ }^{53}$ Gregorius Magnus, Expositio in Canticis Canticorum 20, GMO 8, 18.20.

${ }^{54}$ Gregorius Magnus, Expositio in Canticis Canticorum 15, GMO 8, 14.

${ }_{55}$ Gregorius Magnus, Expositio in Canticis Canticorum 22, GMO 8, 20.

${ }^{56}$ Gregorius Magnus, Expositio in Canticis Canticorum 23, GMO 8, 20.22.

${ }^{57}$ Gregorius Magnus, Expositio in Canticis Canticorum 24, GMO 8, 22.

${ }^{58}$ Gregorius Magnus, Expositio in Canticis Canticorum 25, GMO 8, 22.
} 
matters behind"). The virtue of love is the equivalent of moving into a house and entering the dining room. The virtue of knowledge characterizes all those who live in the Church and are already investigating heavenly mysteries and studying the secret commandments of God. The entrance to the royal bedroom constitutes their counterpart in $\mathrm{Sg}$ ("in cubiculum regis"), which can be accomplished in earthly life through humble contemplation. ${ }^{59}$ Accordingly, faith is the first virtue, and hope, love and finally perfect love, manifested in the study of the mysteries of God, come one by one afterwards. For this reason, the perfect members of the Holy Church are the Saint Doctors of the Church (but also prophets and apostles), who in their lifetime are already filled with divine mysteries and who are able to learn advanced secrets of life in heaven. ${ }^{60}$ Only strong people can acquire contemplation in the Church of God, and the rest (the weak ones, which in $\mathrm{Sg}$ are represented by the maidens) hope that their sins will be forgiven. ${ }^{61}$ The reward of heaven is prepared for those who love God, therefore those Christians who are awaiting the Judge and doing acts of kindness, and who should abandon the fear of the Judge of their deeds and look forward to meeting God, believing that He is on their side. ${ }^{62}$

Sg [1:4-5] (Douay-Rheims: "I am black but beautiful, O ye daughters of Jerusalem, as the tents of Cedar, as the curtains of Solomon. Do not consider that I am brown, because the sun hath altered my colour") This verse, in the symbolic interpretation, represents the cry of the Church against those among the Jews who did not heed Jesus's call to conversion and the prophecies of the Church. In the view of unconverted Jews, it is the Church that is "black," "sinful" and "pagan." But, in reality, it is beautiful as it was enlightened by the grace of God. Another explanation of why the Church is "black" like the tents of Cedar (Kedar) refers to the meaning of "Kedar" itself, which is associated with clouds, or with Kedar as related to Ishmael. That is, just as the tents of Kedar are at the same time the tents of Esau, similarly, the Church can trace its descent from Esau. "Beautiful as the curtains of Solomon" refers to the curtains covering vases in the temple. Souls, being the likeness of God, are compared to those curtains as they hide the only true Solomon, King of Peace. ${ }^{63}$ The change in skin colour is spiritually interpreted as a sign of the transformation that the soul undergoes when touched with grace by the Lord, ${ }^{64}$ or as a blush caused by earthly desires. ${ }^{65}$

"Daughters of Jerusalem" symbolises the children of the Church who come from pagan nations. They are "black," as they were sinful before their conversion,

\footnotetext{
${ }^{59}$ Gregorius Magnus, Expositio in Canticis Canticorum 27, GMO 8, 24.

${ }^{60}$ Gregorius Magnus, Expositio in Canticis Canticorum 26, GMO 8, 24.

${ }^{61}$ Gregorius Magnus, Expositio in Canticis Canticorum 28, GMO 8, 26.

${ }^{62}$ Gregorius Magnus, Expositio in Canticis Canticorum 31, GMO 8, 28.

${ }^{63}$ Gregorius Magnus, Expositio in Canticis Canticorum 32, GMO 8, 28.30.

${ }^{64}$ Gregorius Magnus, Expositio in Canticis Canticorum 33, GMO 8, 30; Expositio in Canticis Canticorum 37, GMO 8, 32.

${ }^{65}$ Gregorius Magnus, Expositio in Canticis Canticorum 39, GMO 8, 34.
} 
but became beautiful as a result of the grace of salvation. For ethno-Christians, the "black tents of Kedar" represents their old, pagan rituals. Ethno-Christians become beautiful ("the curtains of Solomon") by means of their penance.

Sg [1 :5] (Douay-Rheims: "the sons of my mother have fought against me") In Gregory I's allegorical interpretation, these are either the sons of the synagogue, who remained unfaithful to Jesus Christ and fought with the Judeo-Christians who were in the Church of God, ${ }^{66}$ or they are a symbol of man's internal dilemma. ${ }^{67} \mathbf{S g}[\mathbf{1}: \mathbf{5}]$ (Douay-Rheims: "they have made me the keeper in the vineyards: my vineyard I have not kept") According to the allegorical interpretation, "they" denotes the Judeo-Christians who left behind those Jews who were unwilling to believe Christ and went on to propagate the good news to the heathens. ${ }^{68}$

Sg [1 : 6] (Douay-Rheims: "Show me, $O$ thou whom my soul loveth, where thou feedest, where thou liest in the midday") Midday, the time of greatest heat, represents the zeal of faith, love and eager desire for God. Green pastures symbolise virtues. ${ }^{69} \mathrm{Sg}[\mathbf{1}: \mathbf{6}]$ (Douay-Rheims: "lest I begin to wander after the flocks of thy companions") In the allegorical reading, the companions of the groom - that is, of God - are his friends, household members, those who live well. However, the heretics (e.g. Arius, Sabellius or Montanus), or those priests and teachers who do not act in accordance with God's laws, are false companions who can seduce good souls with hypocritical teaching. ${ }^{70}$

$\mathrm{Sg}[1: 7]$ (Douay-Rheims: "If thou know not thyself, O fairest among women, go forth, and follow after the steps of the flocks, and feed thy kids beside the tents of the shepherds"). As regards the spiritual explanation of this verse, the priority of each soul should be attaining self-knowledge and the recognition that they are created in God's image. Following God results from the proper comprehension of this fact and lack of this comprehension means following the beast, destroying oneself with lust and passions. Following the flocks is a symbol of following your carnal desires, temptations and forbidden things. ${ }^{71}$

Sg [1 : 8] (Douay-Rheims: "To my company of horsemen, in Pharao's chariots, have I likened thee, O my love") In the allegorical explanation, the servants of carnal lust, pride, greed, envy and deceit are likened to horses harnessed to the pharaoh's chariot, while the devoted servants of humility, purity, (righteous) learning, and love are compared to horses pulling the chariot of the Creator. ${ }^{72}$ God leads the souls consecrated to Him and cares for them. The pharaoh (demon) does

\footnotetext{
${ }^{66}$ Gregorius Magnus, Expositio in Canticis Canticorum 34, GMO 8, 30; Expositio in Canticis Canticorum 38, GMO 8, 32.

${ }^{67}$ Gregorius Magnus, Expositio in Canticis Canticorum 40, GMO 8, 34.

${ }^{68}$ Gregorius Magnus, Expositio in Canticis Canticorum 35, GMO 8, 35.

${ }^{69}$ Gregorius Magnus, Expositio in Canticis Canticorum 41, GMO 8, 34.36.

${ }^{70}$ Gregorius Magnus, Expositio in Canticis Canticorum 42-43, GMO 8, 36.

${ }^{71}$ Ibidem.

${ }^{72}$ Gregorius Magnus, Expositio in Canticis Canticorum 45, GMO 8, 38.40.
} 
the same, but his chariots and horses will eventually sink in the Red Sea. However, God allows that those people who are still absorbed in carnal lusts (still living as the pharaoh's horses) can change their ways of thinking and proceed to the immersion in baptism. ${ }^{73}$ God, through his mysterious judgments and predestination, accepts that the people who are still committed to lust should convert to good so that they can ultimately serve God. God is also aware of the opposite situation: that many of His servants seem to be serving Him, but they are actually the servants of the pharaoh (demon) by persisting in evil and perversion. Life choices, even those made at the end of life for sanctity and good, ${ }^{74}$ ultimately constitute a test for life devoted to God. $*$

Gregory the Great in his Expositio in Canticis Canticorum, created between the years 594 or 595 and 598, ends the patristic tradition of allegorical commentaries on Sg. We are not in the possession of the complete text of Gregory's commentary, as the text of the Pope's interpretations finishes at $\mathrm{Sg} 1: 8$. Gregory discussed the biblical text in accordance with the principles of intellectual, parenetic and pastoral interpretation. The primary interest of the Pope was to extract the spiritual-mystical meaning of the text, and the allegorical interpretation is supposed to help man read the biblical text so that he can love God and follow Him. The allegorical reading of $\mathrm{Sg}$, and actually of the whole Bible as well, should consequently kindle the love of God in man and fill him with thoughts of God. Gregory I recommends a spiritual-ascetic reading of the Bible: the reader is supposed to change his habits for the better, be able to alienate himself ascetically from the surrounding world, and in this way acquire contemplation of Godly matters (especially the mystery of Incarnation). The things that are absolutely essential for the contemplation of God are: desire for God and His spiritual gifts, listening to Church prophecies, zeal in faith, practising virtues, combating temptations and submitting oneself to God's inspirations. This spiritual intelligence, resulting from the reading of the biblical text, is supposed to lead a Christian to a subtle contemplation of God and life in communion with Him here on the earth.

\section{Summary}

\section{The allegorical sense of Gregory the Great's commentary on the Song of Songs}

Gregory the Great in his Expositio in Canticis Canticorum, created between the years 594 or 595 and 598 , ends the patristic tradition of allegorical commentaries on $\mathrm{Sg}$. We are not in the possession of the complete text of Gregory's commentary, as the text of the Pope's interpretations finishes at Sg $1: 8$. The text of the commentary as we have it at present shows some signs of a revision made by Gregory I himself and has features characteristic of the original oral version of the text. The comparative study

\footnotetext{
${ }^{73}$ Gregorius Magnus, Expositio in Canticis Canticorum 45, GMO 8, 40.

${ }^{74}$ Gregorius Magnus, Expositio in Canticis Canticorum 46, GMO 8, 40.
} 
of Origen's and Gregory's commentaries shows that Pope Gregory I was familiar with Origen's homilies and commentary on $\mathrm{Sg}$ and used his writings while working on his own text, but only sparingly. Gregory I undoubtedly took from Origen the general approach, some phrases, and at times the way in which exegesis of a certain extract was executed. Gregory discussed the biblical text in accordance with the principles of intellectual, parenetic and pastoral interpretation. The primary interest of the Pope was to extract the spiritual-mystical meaning of the text, and the allegorical interpretation is supposed to help man read the biblical text so that he can love God and follow Him. The allegorical reading of $\mathrm{Sg}$, and actually of the whole Bible as well, should consequently kindle the love of God in man and fill him with thoughts of God. Gregory I recommends a spiritual-ascetic reading of the Bible: the reader is supposed to change his habits for the better, be able to alienate himself ascetically from the surrounding world, and in this way acquire contemplation of Godly matters.

\section{Keywords}

Allegory, Gregory the Great, Song of Songs, sense 